\title{
Przemysław Dyjak
}

Uniwersytet Ekonomiczny w Katowicach

e-mail: dyjakp@gmail.com

ORCID 0000-0001-6104-7628

\section{ANALIZA KONKURENCYJNOŚCI WĘGLA \\ W POLSKIM SEKTORZE ENERGETYCZNYM \\ W ODNIESIENIU DO DYREKTYW \\ UNII EUROPEJSKIEJ DO 2050 ROKU}

\section{ANALYSIS OF COAL'S COMPETITIVENESS \\ IN THE POLISH POWER SECTOR IN RELATION \\ TO EUROPEAN UNION DIRECTIVES UNTIL 2050}

DOI: $10.15611 / \mathrm{e} 21.2018 .2 .05$

JEL Classification: Q20, Q30, Q42

Streszczenie: $Z$ roku na rok można zaobserwować wzrost temperatury na świecie. Naukowcy alarmują, iż skutki zmian klimatu mogą być nieodwracalne. Ocieplający się klimat spowodował, iż Unia Europejska zaczęła przywiązywać dużą wagę do zahamowania tego procesu. Podjęła działania i wprowadziła politykę energetyczną dla całej Wspólnoty w postaci dyrektyw. Celem polityki UE jest zwiększenie udziału odnawialnych źródeł energii w sektorze energetycznym, jak również zmniejszenie emisji $\mathrm{CO}_{2}$, m.in. poprzez redukcję węgla w produkcji energii, a do roku 2050 wyeliminowanie węgla z sektora energetycznego. Od wielu lat filarem polskiego sektora energetycznego jest węgiel, ze względu na zasoby tego surowca. Odnawialne źródła energii nie są najmocniejszą stroną w polskim sektorze energetycznym i stanowią niewielki procent. Jednakże z każdym rokiem udział ten systematycznie wzrasta. $\mathrm{W}$ artykule przedstawiono sytuację węgla $\mathrm{w}$ polskim sektorze energetycznym $\mathrm{w}$ dobie promowania przez Unię Europejską odnawialnych źródeł energii. W badaniu została również dokonana analiza SWOT węgla oraz OZE w polskim sektorze energetycznym. Podjęto również próbę odpowiedzi na pytanie o konkurencyjność węgla jako paliwa w najbliższych latach.

Słowa kluczowe: sektor energetyczny, górnictwo, odnawialne źródła energii.

Summary: The global increase of temperature can be observed every year. Scientists alert us to the fact that climate changes may be irreversible. The ever warmer climate has made the European Union pay more attention to methods of tackling this problem. The EU has undertaken actions and implemented a power policy for the entire Community in the form of Directives. The objective of the EU policy is to increase the share of renewable energy sources in the power sector, as well as to decrease the levels of $\mathrm{CO}_{2}$ emissions through the reduction of coal use in power generation and through the elimination of coal from the power sector altogether by 2050. Coal has been the cornerstone of the Polish power sector for many years 
because of the natural resources of this particular material. Renewable energy sources are not the strongest part of the Polish power sector and comprise only a small percentage thereof. However, this share is systematically increasing every year. This paper presents the position of coal in the Polish power sector in the age of renewable energy sources promoted by the European Union. It also provides a SWOT analysis for coal and for RES in the Polish power sector. An attempt to answer the question of coal competitiveness as a fuel in the next few years has also been made, using the presented scenarios.

Keywords: power sector, mining, renewable energy sources.

\section{Wstęp. Rozwój rynku odnawialnych źródeł energii w Unii Europejskiej}

Początkiem formalnej współpracy państw członkowskich WE w zakresie polityki był podpisany w 1964 r. Protokół w sprawie podjęcia kroków na rzecz wypracowania wspólnej polityki energetycznej. Na podstawie tego dokumentu Rada Unii Europejskiej w 1969 r. przedstawiła wstępne zasady funkcjonowania tej polityki ${ }^{1}$. W 1976 r. uzgodniła plan działania na wypadek potencjalnego załamania się podaży ropy naftowej. Działania te były zgodne z planem przygotowanym przez Międzynarodową Agencję Energetyczną i opierały się na dzieleniu z pozostałymi państwami WE posiadanymi zasobami ropy². W 1990 r. Komisja została zobowiązana do włączenia odnawialnych źródeł energii do polityki energetycznej Wspólnoty. W 1993 r. pierwsze konkretne cele rozbudowy odnawialnych źródeł energii zostały sformułowane w ramach programu Altener - miały na celu wsparcie projektów pilotażowych w obszarze produkcji energii elektrycznej ze źródeł odnawialnych. Ważnym wydarzeniem było uchwalenie w 1995 r. przez Komisję Europejską Białej księgi. Dzięki temu odnawialne źródła energii powiązane zostały również z kwestią ochrony środowiska. W dokumencie zawarto potrzebę wprowadzenia stosownych regulacji i sposobów finansowania, które przyspieszyłyby ich rozbudowę. Od początku integracji w Europie towarzyszyły im wspólnotowe przedsięwzięcia w dziedzinie ochrony środowiska i przeciwdziałania jego degradacji, a szczególnym wyrazem tych działań było wprowadzenie do traktatu wspólnotowej polityki ochrony środowiska ${ }^{3}$. Niespełna dwa lata później, 11 listopada 1997 r., Komisja Europejska przyjęła kolejną białą księgę: Energia dla przyszłości: odnawialne źródła energii ${ }^{4}$. Rozwijanie energetyki odnawialnej ma za zadanie zwiększyć bezpieczeństwo zaopatrzenia

${ }^{1}$ Z.M. Doliwa-Klepacki, Integracja europejska, Temida 2, Białystok 2005, s. 551.

${ }^{2}$ Ibidem, s. 552.

${ }^{3}$ G. Wojtkowska-Łodej, Manteuffel W., 2009, Uwarunkowania, wyzwania i perspektywy dla polityki energetycznej Polski w kontekście polityki klimatycznej, Fundacja Centrum Stosunków Międzynarodowych, Warszawa, s. 64-79.

${ }^{4}$ Biała księga ,Energia dla przyszłości - odnawialne źródła energii”, $\operatorname{KOM(97)599,~wersja~os-~}$ tateczna. 
energetycznego UE i ograniczyć zależność od importu paliw kopalnych, zmniejszyć emisję gazów cieplarnianych, jak również zwiększyć ekonomiczną konkurencyjność UE. Kolejnym ważnym wydarzeniem jest przyjęty przez Komisję Europejską w 2007 r. pakiet działań w obszarze energii i zmian klimatu na poczet redukcji gazów cieplarnianych. W latach 2007-2009 na energię odnawialną przeznaczono ok. 9,8 mld euro, z czego większość w formie pożyczek Europejskiego Banku Inwestycyjnego. W komunikacie z listopada 2010 r. „Europa 2020” Komisja podkreśla, iż konkurencyjność, bezpieczeństwo dostaw oraz cele klimatyczne będą zagrożone, jeśli nie nastąpi modernizacja sieci elektroenergetycznych. Zostaje wprowadzona zasada $3 \times 20$ :

- ograniczyć emisję dwutlenku węgla co najmniej o $20 \% \mathrm{w}$ porównaniu z poziomem z $1990 \mathrm{r}$. lub, jeśli pozwolą na to warunki, o 30\%,

- zwiększyć udział odnawialnych źródeł energii w naszym całkowitym zużyciu energii do $20 \%$,

- zwiększyć efektywność wykorzystania energii o $20 \%{ }^{5}$.

Zasada $3 \times 20$ stwarza nadzieję na osiągnięcie w dłuższej perspektywie stabilizacji zmian klimatycznych.

Strategia energetyczna do roku 2020 koncentruje wysiłki na:

- działaniu na rzecz poprawy efektywności energetycznej,

- rozwoju technologii energetycznych oraz innowacji,

- utworzeniu zintegrowanego ogólnoeuropejskiego rynku energii.

Osiągnięcie celu $20 \%$ będzie wymagało ogromnego wzrostu we wszystkich trzech sektorach energetyki odnawialnej, czyli w elektroenergetyce, biopaliwach oraz w sektorze ogrzewania i chłodzenia. W 2020 r. z odnawialnych źródeł energii może pochodzić ok. jedna trzecia energii elektrycznej zużywanej w $\mathrm{UE}^{6}$. W sektorze energetycznym w UE do 2020 roku trzeba zainwestować ponad 1 bilion euro ${ }^{7}$. W ogłoszonym w styczniu 2014 r. komunikacie Komisji sformułowany został program ramowy na rzecz klimatu i energii od 2020 do 2030 r., w którym określono zobowiązanie do dalszej redukcji emisji gazów cieplarnianych i zapoczątkowano proces dochodzenia do wspólnej koncepcji jej przyszłej realizacji.

Obecnie ostatnim planem Komisji Europejskiej jest „Mapa drogowa 2050”. Infrastruktura energetyczna, która w 2050 r. będzie zasilać domy mieszkalne, przemysł i usługi, a także budynki, z których będziemy w przyszłości korzystać, jest obecnie na etapach projektowania i realizacji. Określono, że energia elektryczna będzie musiała odgrywać znacznie większą rolę niż obecnie. UE jest zdecydowana, aby do 2050 r. zmniejszyć emisje gazów cieplarnianych o 80-95\% w stosunku do wielkości

${ }^{5}$ Komisja Europejska, 2010, Komunikat Europa 2020. Strategia na rzecz inteligentnego i zrównoważonego sprzyjającego włączeniu społecznemu, Bruksela z dnia 3.3.2010 KOM (2010) 2020 s. 12.

${ }^{6}$ Komunikat Komisji do Rady Europejskiej i Parlamentu Europejskiego, Europejska Polityka Energetyczna, KOM (2007)1, s. 15.

${ }^{7}$ Pakiet dotyczący Unii Energetycznej, Bruksela z dnia 25.2.2015 r. COM(2015)80, s. 3. 
emisji w latach 90. XX wieku' . Cel ten ma być realizowany dzięki pełnej implementacji już przyjętej polityki i dyrektyw oraz dalszemu zaostrzaniu ETS po roku 2020. Założenia planu „Mapa drogowa 2050” napotkały duży opór ze strony Polski. Tak znaczna redukcja emisji gazów cieplarnianych może zagrozić bezpieczeństwu energetycznemu ze względu na to, iż energetyka kraju oparta jest w głównej mierze na spalaniu węgla.

\section{Bezpieczeństwo energetyczne}

W ostatnich latach bezpieczeństwu energetycznemu poświęcono wiele uwagi. Temat pojawiał się w wielu aktach prawnych oraz raportach. Pojęcie bezpieczeństwa energetycznego zostało zdefiniowane w dokumencie Polityka energetyczna Polski do $2025 \mathrm{r}$.

Bezpieczeństwo energetyczne to stan gospodarki umożliwiający pokrycie bieżącego i perspektywicznego zapotrzebowania odbiorców na paliwa i energii, w sposób technicznie i ekonomicznie uzasadniony, przy minimalizacji negatywnego oddziaływania sektora energii na środowisko i warunki życia społeczeństwa9

Poziom bezpieczeństwa energetycznego zależy od wielu czynników, z których najważniejsze to:

- stopień zrównoważenia popytu i podaży na energię i paliwa, z uwzględnieniem aspektów strukturalnych i przewidywanego poziomu cen,

- zróżnicowanie struktury nośników energii tworzących krajowy bilans paliwowy,

- stopień zdywersyfikowania źródeł dostaw przy akceptowalnym poziomie kosztów oraz przewidywanych potrzebach,

- stan techniczny i sprawność urządzeń i instalacji, w których następuje przemiana energetyczna nośników energii oraz systemów transportu, przesyłu i dystrybucji paliw i energii,

- stany zapasów paliw w ilości zapewniającej utrzymanie ciągłości dostaw do odbiorców,

- uwarunkowania ekonomiczne funkcjonowania przedsiębiorstw energetycznych i ich wyniki finansowe,

- kondycja ekonomiczno-finansowa użytkowników paliw i energii, zarówno gospodarstw domowych, jak i przedsiębiorstw,

- stan lokalnego bezpieczeństwa energetycznego, tj. zdolności do zaspokojenia potrzeb energetycznych na szczeblu lokalnych społeczności ${ }^{10}$.

\footnotetext{
${ }^{8}$ Plan działania w zakresie energii do roku 2050. $\operatorname{KOM}(2011)$ 885, s. 2.

${ }^{9}$ Biuletyn Urzędu Regulacji i Energetyki, 2005, nr 6, s. 17.

${ }^{10}$ Polityka Energetyczna Polski do 2025 roku, dokument przyjęty przez Radę Ministrów w dniu 4 stycznia 2005 roku, s. 5.
} 


\section{Emisja $\mathrm{CO}_{2}$ w polskim sektorze energetycznym}

Polski sektor energetyczny opiera się na węglu. Jednakże tak duże zapotrzebowanie na węgiel przyczynia się do wytwarzania ogromnych emisji do atmosfery związków chemicznych, z czego $\mathrm{CO}_{2}$ może stanowić około $92 \%$. O tak dużej ilości emitowanych zanieczyszczeń świadczy wiek elektrowni w Polsce. Struktura wiekowa kotłów pracujących w polskich elektrowniach wskazuje, że ponad połowa pracuje już prawie 30 lat. Stąd przypuszczenia, że w najbliższych latach będą one sukcesywnie wycofywane z systemu elektroenergetycznego ${ }^{11}$. Należy również podkreślić, że krajem o największej emisji są Chiny. W 2014 roku wyemitowały one ponad 9,76 mld ton $\mathrm{CO}_{2}$, co stanowiło $27,1 \%$ światowej emisji. Kolejnym państwem były USA $-5,99$ mld ton z produkcją $16,9 \%$, oraz UE $-3,7$ mld ton $(11,2 \%)$. W UE liderem są Niemcy -788 ton $(2,4 \%)$. W Polsce wyemitowano $316 \mathrm{mln}$ ton $(0,9 \%$ światowej emisji). Polska z tą emisją uplasowała się dopiero na 23 miejscu $^{12}$.

Tabela 1. Emisja $\mathrm{CO}_{2}$ w latach 1988-2016 w kilotonach ekwiwalentu $\mathrm{CO}_{2}$

\begin{tabular}{|l|c|c|c|c|c|c|c|c|c|c|c|c|c|c|c|}
\hline Rok & 1988 & 2003 & 2004 & 2005 & 2006 & 2007 & 2008 & 2009 & 2010 & 2011 & 2012 & 2013 & 2014 & 2015 & 2016 \\
\hline $\mathrm{CO}_{2}$ & 470 & 318 & 322 & 321 & 334 & 334 & 327 & 314 & 332 & 331 & 324 & 319 & 307 & 310 & $\mathbf{3 2 2}$ \\
\hline
\end{tabular}

Źródło: opracowanie własne na podstawie Krajowego Raportu Inwentaryzacji 2018.

Odwołując się do tab. 1, można zaobserwować, iż z pozycji bazowej z 1988 roku do 2016 roku emisję $\mathrm{CO}_{2}$ udało się ograniczyć o 32\%. Do tak dużego udziału procentowego na pewno przyczyniła się transformacja przemysłu ciężkiego, jak również spadek wydobycia węgla. Najwięcej $\mathrm{CO}_{2}$ pochodziło ze spalania paliw - około $92 \%$, z czego aż 50\% z energetyki. Obecnie w Polsce realizowanych jest kilka inwestycji związanych z budową nowych mocy wytwórczych zasilanych węglem. W najbliższych latach zostaną uruchomione następujące nowe bloki energetyczne. Blok 1075 MW w Elektrowni Kozienice (2018 r.), blok 496 MW w Elektrowni Turów (2018 r.), 2 bloki po 900 MW w Elektrowni Opole (2019 r.) oraz blok 910 MW w Elektrowni Jaworzno III (2019 r.). Nowe inwestycje sprawią, że ubytki związane z wycofaniem starych jednostek powinny zostać do roku 2020 uzupełnione. Nowe inwestycję będą bardziej przyjazne dla środowiska dzięki wdrażaniu nowych technologii.

\section{Nowe technologie spalania węgla}

Głównym problemem spalania węgla w energetyce jest powstanie dużych emisji dwutlenku węgla. Obecnie emituje się około 1 tony $\mathrm{CO}_{2} / \mathrm{MWh}$. Dla porównania gaz ziemny emituje około 0,4 tony $\mathrm{CO}_{2} / \mathrm{MWh}$, a energia atomowa 0,2 tony $\mathrm{CO}_{2} / \mathrm{MWh}$.

${ }^{11}$ H. Kaproń, Z. Połecki, 2012, Eksploatacja podsystemu wytwórczego w Polsce w latach 1995-2010, Rynek Energii, nr 6, s. 3-9.

${ }^{12}$ Węgiel brunatny. Biuletyn informacyjny, 2015, nr 4 (93) s. 8. 
Ze względu na tak duże emisje Unia Europejska stara się wyprzeć węgiel z produkcji energii. Polski sektor energetyczny od lat w znacznej mierze opiera się na węglu. W ramach Wspólnoty prowadzi także zakrojone na szeroką skalę badania nad nowymi czystymi technologiami przetwarzania konwencjonalnych źródeł energii bez konieczności i ryzyka emisji gazów cieplarnianych do atmosfery. Badania prowadzą m.in. Instytut Energetyki, Akademia Górniczo-Hutnicza, Główny Instytut Górnictwa w Katowicach, Instytut Chemicznej Przeróbki Węgla z Zabrza oraz Politechnika Śląska w Gliwicach. Przez czyste technologie węglowe rozumiemy technologie zaprojektowane w celu poprawy skuteczności wydobycia, przeróbki, przetwarzania oraz utylizacji węgla i zwiększenia akceptowalności tych procesów ze względu na ich wpływ na środowisko naturalne.

Czyste technologie węglowe można podzielić na:

1. Podobszary, z którymi wiążą się czyste technologie węgla:

- wydobycie węgla i przeróbka,

- transport, składowanie węgla i uśrednianie węgla,

- wykorzystanie węgla w energetyce,

- zagospodarowanie pozostałości z wydobycia i wykorzystania węgla, czyli różnego rodzaju odpadów.

2. Procesy, z którymi wiążą się czyste technologie węgla:

- w procesie zgazowania:

- układy gazowo-parowe ze zintegrowanym zgazowaniem paliw,

- zgazowanie podziemne;

- w procesie spalania:

- nadkrytyczne siłownie z kotłami parowymi,

- siłownie z kotłami fluidalnymi,

- spalanie w atmosferze wzbogaconej w tlen;

- w procesie oczyszczania spalin:

- odsiarczanie,

- selektywna katalityczna redukcja tlenków azotu,

- selektywna niekatalityczna redukcja tlenków azotu,

- sekwestracja $\mathrm{CO}_{2}$,

- odpylanie.

Dużym zainteresowaniem cieszy się proces zgazowania węgla. Podziemne zgazowanie węgla to sposób eksploatacji złóż węgla, polegający na zamianie węgla bezpośrednio w miejscu jego zalegania na gaz o składzie kwalifikującym go do przemysłowego stosowania. Proces zgazowania węgla nie jest technologią nową, lecz ewoluującą od dziesiątek lat. W ostatnich latach technologia zgazowania węgla przechodzi znaczną transformację z powodu nowych rozwiązań technologicznych, prowadzonych badań oraz wymiany doświadczeń.

Proces zgazowania węgla ma wiele zalet, takich jak:

- możliwość wykorzystania złóż, których eksploatacja tradycyjnymi metodami nie może być prowadzona lub jest nieopłacalna, 
- możliwość wykorzystania złóż pozostałych w zlikwidowanych kopalniach, relatywnie niskie koszty technologii,

- produkcja wodoru i metanolu z węgla może być szansą na poprawę bezpieczeństwa energetycznego kraju,

- nie powoduje dużych deformacji na powierzchni.

Produktem ze zgazowania węgla jest syngaz, który może być wykorzystywany do produkcji energii w układzie gazowo-parowym. Może być użyty również do produkcji produktów chemicznych, jak metanol i wodór, a także w syntezie chemicznej. W 2014 r. światowa liczba istniejących instalacji zgazowania wyniosła 272 (o łącznej mocy 116,6 GWth). Proces ten już jest stosowany w USA, Australii czy Chinach. Polska również mogłaby go stosować, przyczyniając się do realizacji umów redukcji gazów cieplarnianych oraz poprawy jakości powietrza. Wykorzystanie potencjału nowych technologii powinno być naturalnym krokiem w stosunku do znacznych zasobów węgla oraz polityki energetycznej w Polsce.

\section{Sektor energetyczny w Polsce}

Sektor energetyczny w Polsce ma zapewnić bezpieczeństwo dostaw energii. Od lat głównym surowcem w sektorze energetycznym jest węgiel. Surowiec ten jest odpowiedzialny za około $80 \%$ produkcji energii elektrycznej ogółem. Świadczy o tym fakt, iż Polska ma znaczne ilości tego surowca. Za realizację i bezpieczeństwo odpowiadają: Ministerstwo Gospodarki, Ministerstwo Środowiska, Ministerstwo Skarbu Państwa.

Polski sektor energetyczny jest trzecim pod względem wielkości produkcji energii elektrycznej z paliw stałych w Europie ${ }^{13}$, na świecie zaś Polska zajmuje dziewiątą lokatę. Według bilansu zasobów złóż kopalin w Polsce według stanu na 31.12.2014 r. zasobów bilansowych węgla brunatnego jest 23,5 mld ton, a węgla kamiennego 52,0 mld ton. Uwzględniając, że od 1945 r. w Polsce wydobyto łącznie około $3 \mathrm{mln}$ ton węgla brunatnego oraz 9 mld ton węgla kamiennego, można śmiało stwierdzić, że zasoby te mogą wystarczyć na kolejne 200-300 lat ${ }^{14}$. Ubiegłoroczna sprzedaż węgla - w kraju i na eksport - osiągnęła poziom 73,1 mln ton, z czego $59,6 \mathrm{mln}$ ton to węgiel energetyczny, a 13,5 mln ton - koksowy, którego sprzedaż wzrosła wobec 2015 r. o 3,9\%. Zeszłoroczna wielkość sprzedaży była porównywalna z tą z 2015 r., kiedy odbiorców znalazło łącznie 73,5 mln ton węgla. Na koniec lipca 2017 r. w polskim górnictwie pracowało około 82 tys. osób. Jak pokazują

${ }^{13}$ G. Wojtkowska-Łodej, 2015, Polityka klimatyczno-energetyczna Unii Europejskiej - wyzwania dla przyszłości polskiej gospodarki, t. 18, z. 1, s. 19.

${ }^{14}$ Z. Kasztelewicz, M. Zajączkowski, M. Ptak, 2015, Strategiczne determinanty rozwoju górnictwa $i$ energetyki węgla brunatnego w Polsce, Zeszyty Naukowe Instytutu Gospodarki Surowcami Mineralnymi i Energią Polskiej Akademii Nauk, nr 91, s. 105. 
dane za wrzesień 2017 r., procentowy udział produkcji krajowej energii elektrycznej kształtował się następująco:

- energia z węgla około $80 \%$,

- energia $\mathrm{z}$ wiatru około $8 \%$,

- energia z pozostałych źródeł około $6,5 \%$,

- energia z gazu około 4\%,

- energia $\mathrm{z}$ wody $1,5 \%$.

Tabela 2. Analiza SWOT wykorzystania węgla w polskim sektorze energetycznym

\begin{tabular}{|c|c|}
\hline Mocne strony & Słabe strony \\
\hline 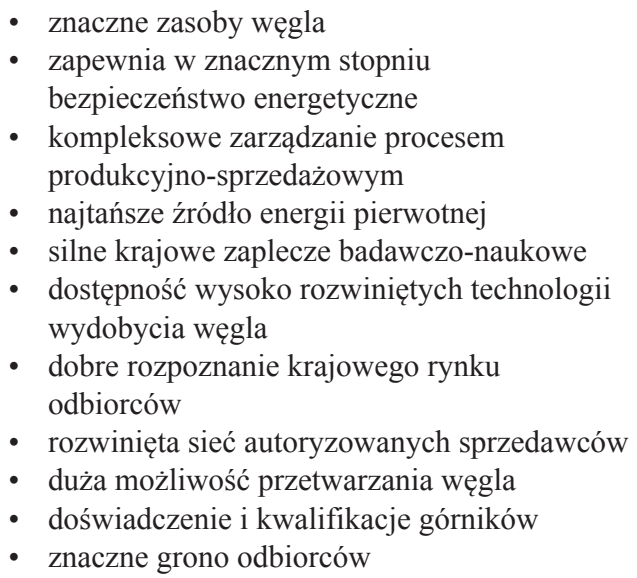 & 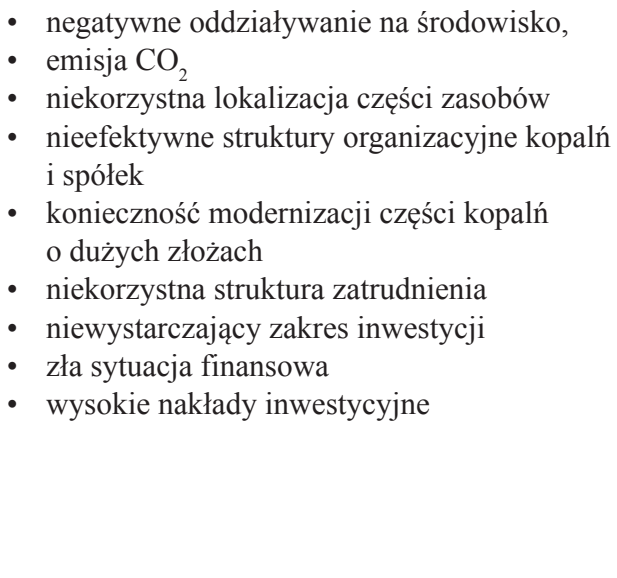 \\
\hline Szanse & Zagrożenia \\
\hline 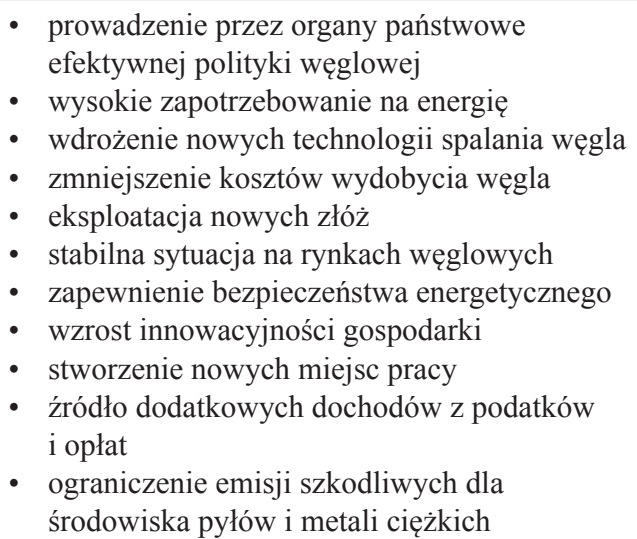 & $\begin{array}{l}\text { - } \text { zaostrzająca się polityka klimatyczna UE } \\
\text { - } \text { nadwyżka węgla na rynkach } \\
\text { - } \text { konkurencja ze strony importerów węgla } \\
\text { - } \text { zanieczyszczenie środowiska } \\
\text { - } \text { wzrastająca konkurencyjność innych } \\
\text { nośników energii } \\
\text { - brak rozwiązań prawnych zabezpieczających } \\
\text { - } \text { strategiczne złoża } \\
\text { - } \text { brak wyedycja węgla od jednego przewoźnika } \\
\text { do realizacji programów }\end{array}$ \\
\hline
\end{tabular}

Źródło: opracowanie własne.

W przedstawionej analizie SWOT więcej uwagi warto poświęcić słabym stronom. Należałoby się skupić na usprawnieniu systemu zarządzania. Nieefektywne zarządzanie wpływa na wiele czynników, m.in. jakość funkcjonowania kopalń, 
produktywność pracowników, jak również na procesy rozwoju i modernizacji. Niewłaściwe zarządzanie rzutuje na funkcjonowanie całego sektora górniczego. Przy obecnie prowadzonej polityce energetycznej opartej na węglu nie można dopuścić do tąpnięcia w sektorze węglowym, którego jednym z elementów jest zarządzanie. Zaniechanie tak ważnego czynnika może już w niedalekiej przyszłości pociągnąć za sobą daleko idące konsekwencje.

Należy również wspomnieć, iż nie wszystkie kopalnie wydobywają węgiel. W 2000 roku w wyniku połączenia kopalń KWK Jan Kanty, KWK Porąbka-Klimontów, KWK Saturn oraz KWK Sosnowiec została powołana Spółka Restrukturyzacji Kopalń. Powodem likwidacji i przerwania wydobycia były wyniki ekonomiczne oraz brak warunków do osiągnięcia trwałej rentowności. Likwidowanie kopalń $\mathrm{w}$ perspektywie długoterminowej przyczyni się do ograniczenia wydobycia węgla, lecz nie do całkowitego zaniku w sektorze energetycznym ze względu na zapewnienie bezpieczeństwa energetycznego, jak również zasoby naturalne surowca.

Polski sektor energetyczny to nie tylko węgiel, lecz również odnawialne źródła energii (OZE). Do energii ze źródeł odnawialnych zaliczyć można: energię wodną, energię geotermalną, energię prądów morskich, pływów i falowania, energię słoneczną, energię wiatru, biopaliwo, biomasę, biogaz, energię cieplną oceanu ${ }^{15}$.

Tabela 3. Analiza SWOT wykorzystania odnawialnych źródeł energii w polskim sektorze energetycznym

\begin{tabular}{|c|c|}
\hline Mocne strony & Słabe strony \\
\hline $\begin{array}{l}\text { - źródło dodatkowych dochodów z podatków } \\
\text { i opłat } \\
\text { - } \text { ograniczenie emisji szkodliwych pyłów PM10 } \\
\text { oraz P2,5 do atmosfery - niska emisyjność } \mathrm{CO}_{2} \\
\text { - } \text { poparcie i promowanie przez UE OZE } \\
\text { - } \text { niewyczerpalność niektórych źródeł } \\
\text { systematyczne zwiększenie udziału OZE } \\
\text { w sektorze energetycznym }\end{array}$ & 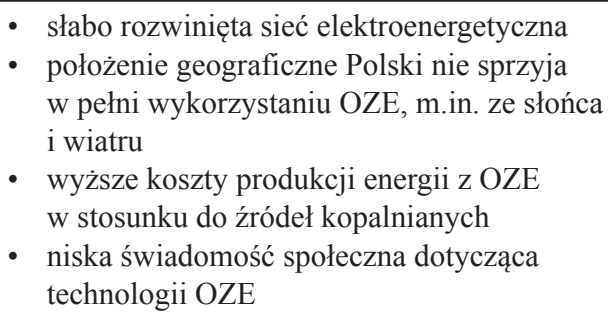 \\
\hline Szanse & Zagrożenia \\
\hline $\begin{array}{ll}\text { - } & \text { nowe miejsca pracy } \\
\text { - } & \text { napływ nowych inwestorów i technologii } \\
\text { - } & \text { poprawa bezpieczeństwa energetycznego } \\
\text { - } & \text { rozwójój gospenie emisji } \mathrm{CO}_{2} \\
\text { redarczy }\end{array}$ & $\begin{array}{l}\text { - opór lokalnych społeczności } \\
\text { - działalność lobby energetyki opartej na } \\
\text { źródłach kopalnianych } \\
\text { - zmienność przepisów prawnych }\end{array}$ \\
\hline
\end{tabular}

Źródło: opracowanie własne.

W przedstawionej w tab. 3 analizie SWOT wykorzystania odnawialnych źródeł energii warto podkreślić położenie geograficzne Polski. Nie wszystkie odnawialne

${ }^{15}$ M. Urbańska-Malucha, 2013, Rynkowe mechanizmy w ochronie klimatu w Unii Europejskiej i w Polsce, Wrocław, s. 168. 
źródła energii można w pełni wykorzystać w Polsce. Dużym atutem dla nowych projektów jest dostęp do morza oraz pasm górskich. Obecnie można zaobserwować znaczny opór lokalnych społeczności, szczególnie osób sędziwych, wobec nowych inwestycji. Niewiedza, mentalność, jak również niechęć do zmian to główne powody konfliktów związanych z OZE.

Zasoby źródeł energii odnawialnej i perspektywiczne możliwości ich wykorzystania są w zasadzie nieograniczone. Mimo trwającej od dziesięcioleci rewolucji technologicznej wykorzystanie zasobów jest niewspółmiernie małe w porównaniu $z$ drzemiącym $w$ nich potencjałem. OZE pozwalają na zmniejszenie intensywności eksploatacji kopalnych surowców energetycznych, przy czym w znacznym stopniu zmniejszają szkodliwe oddziaływanie na środowisko naturalne, głównie przez ograniczenie emisji szkodliwych substancji. Dopiero przystąpienie Polski do Unii Europejskiej i realizacja polityki energetycznej przyczyniły się do rozwoju OZE w sektorze energetycznym. Obecnie głównym bodźcem pobudzającym wzrost OZE w sektorze jest dyrektywa 2009/28/WE ${ }^{16}$, która określa wytyczne dla Polski w tym obszarze. Jednym z głównych jej celów jest zwiększenie udziału odnawialnych źródeł energii w naszym całkowitym zużyciu energii do 15\%. Udział OZE z każdym rokiem wzrasta - w 2015 r. osiągnięto jego udział na poziomie 11,7\%. Największy udział według nośników został zanotowany z wiatru i biomasy. W 2016 r. sektor OZE wyprodukował ponad 19 tys. GWh energii. Ze względu na uwarunkowania prawne, ekonomiczne, jak również geograficzne przyrost energii z OZE się zwiększa, lecz w wolnym tempie. Siła wzmacniająca aktualnie konkurencyjność polskiego górnictwa węgla wynika z ograniczonej dostępności substytutów, co oznacza brak wystarczających zasobów pozostałych surowców energetycznych. Gospodarka Polski od wielu lat wykorzystuje do produkcji energii elektrycznej przede wszystkim węgiel, który ze względu na zasobność złóż krajowych jest również gwarantem krajowego bezpieczeństwa energetycznego ${ }^{17}$. Obecne nastawienie do wytwarzania przez UE energii z węgla jest negatywne. Nie ma wątpliwości co do promowania i zwiększania produkcji energii z OZE. Prawie znikoma emisja $\mathrm{CO}_{2}$ pochodząca z tych źródeł oraz niewyczerpywalność zasobów niektórych źródeł jest dużym atutem. Jednakże węgiel może być również atrakcyjną alternatywą w dobie dzisiejszych technologii.

\section{Przyszłość węgla w sektorze energetycznym do 2050 roku}

Po przeprowadzonej analizie SWOT nasuwa się pytanie o przyszłość węgla w sektorze energetycznym w perspektywie długoterminowej. Przewidywań, jak również prognoz jest wiele. Pozytywne scenariusze dla węgla w polskim sektorze energetycznym przedstawiono na rys. 1 .

\footnotetext{
${ }^{16}$ Dyrektywa Parlamentu Europejskiego i Rady 2009/28/WE z dnia 23 kwietnia 2009 r.

${ }^{17}$ M. Turek, I. Jonek-Kowalska, 2014, Zeszyt Naukowy Politechniki Śląskiej nr kol. 1921, s. 454.
} 


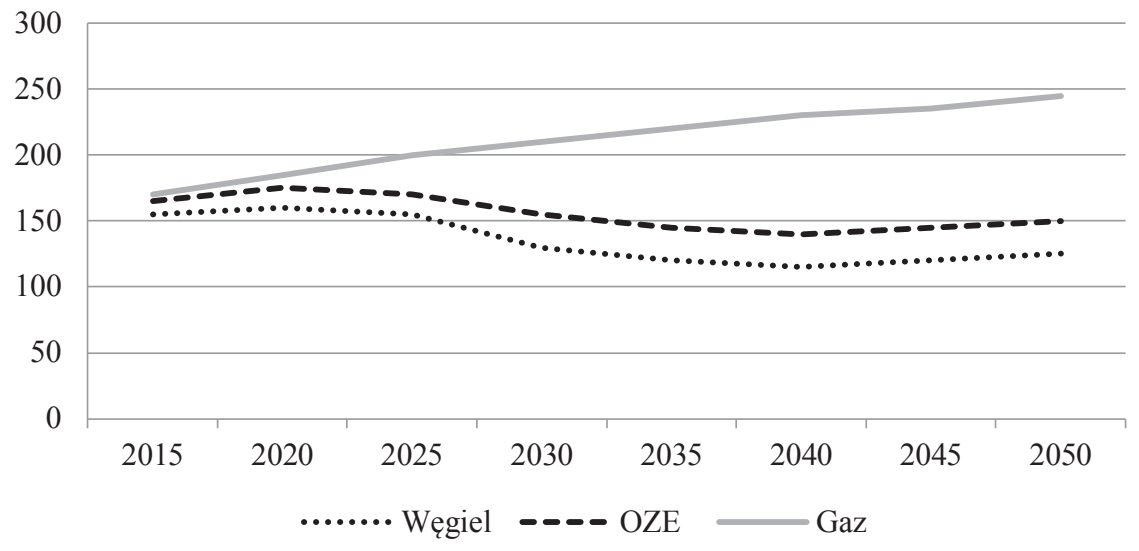

Rys. 1. Scenariusz referencyjny

Źródło: opracowanie własne na podstawie: Ministerstwo Energetyki. Bezpieczeństwo dostaw energii elektrycznej, Konwent Marszałków Województw RP, 2014.
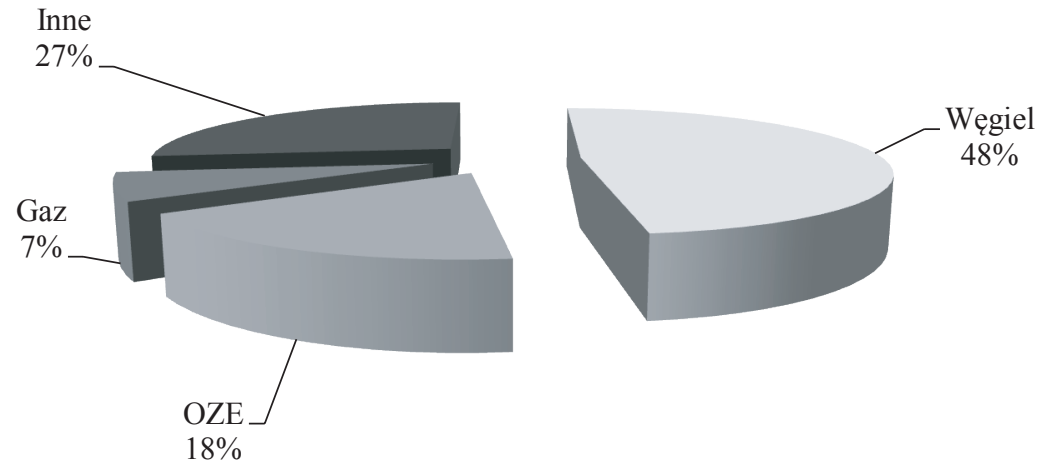

Rys. 2. Scenariusz Primes-Ref

Źródło: opracowanie własne na podstawie: A. Wyrwa, A. Szurlej, L. Gawlik, W. Suwała, 2015, Energy scenarios for Poland - a comparison of PRIMES and TIMES - PL modeling results, Journal of Power Technologies.

Na podstawie przedstawionych scenariuszy można przyjąć, że w dłuższej perspektywie bilans energetyczny będzie związany z dominacją udziału węgla. Na taki stan może wpłynąć rentowność, efektywność ekonomiczno-finansowa górnictwa oraz zrównoważony rozwój dzięki racjonalnemu i oszczędnemu pozyskaniu, jak również wykorzystaniu surowca. Jednakże prognozy dla węgla w perspektywie długoterminowej przedstawiają tendencję spadkową. Można domniemywać, iż dominacja węgla w sektorze energetycznym do 2050 roku będzie wiązała się z mniejszym wydobyciem związanym z wykorzystaniem nowych technologii oraz rozwojem OZE. 
Powstały również prognozy znacznie mniej optymistyczne niż przedstawione powyżej. Głównie za sprawą prowadzonej polityki Unii Europejskiej.

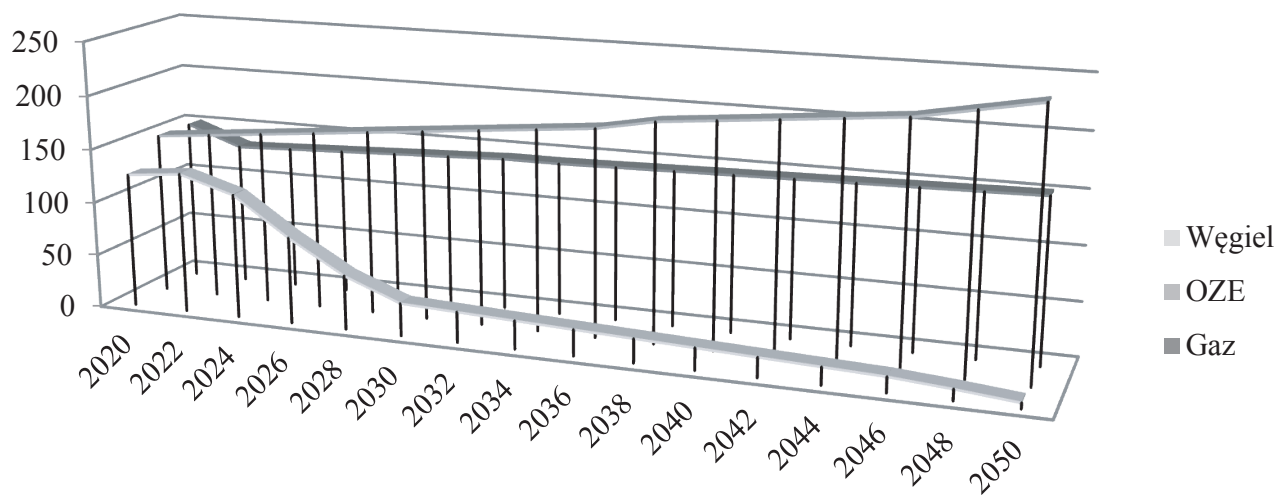

Rys. 3. Scenariusz Komisji Europejskiej

Źródło: opracowanie własne na podstawie: Ministerstwo Gospodarki, załącznik 2 do Polityki energetycznej Polski do 2050 roku.

Negatywny scenariusz Komisji Europejskiej dla polskiego sektora energetycznego kreuje całkowitą rezygnację z węgla w procesie produkcji energii ze względu na prowadzoną politykę. Prowadzona polityka Unii Europejskiej niesie ze sobą dla polskiej gospodarki daleko idące konsekwencje. Może przyczynić się w gospodarce do:

- spadku PKB,

- pogorszenia się konkurencyjności przemysłu,

- braku ekonomicznych bodźców do podejmowania inwestycji w energetyce węglowej,

- wzrostu bezrobocia,

- uzależnienia polskiej energetyki od dostawców zewnętrznych.

W społeczeństwie może dojść do:

- pogorszenia jakości życia obywateli,

- wzrostu cen energii.

Przedstawiony scenariusz nie jest przesądzony. Zasoby węgla w polskim sektorze energetycznym są dużym atutem, a jednocześnie kolidują z zapewnieniem bezpieczeństwa energetycznego przez politykę Unii Europejskiej. Czy istnieje złoty środek? Węgiel powinien odgrywać istotną rolę ze względu na zasoby owego surowca oraz brak alternatyw. Zapewnienie bezpieczeństwa energetycznego w kraju wyłącznie z OZE, nie mając chociażby energii atomowej, jest mało realne. Ważnym czynnikiem jest zmiana strategii branży górniczej. W dobie postępu technologicznego oraz prężnie działającego zaplecza badawczo-naukowego górnictwo powinno stawiać na innowacje i szybki rozwój. Warto deliberować na temat przejścia z prawa unijnego hard law na soft law. Obecne prawo unijne hard law ściśle określa kierunek 
oraz wytyczne. Ambitny plan Komisji Europejskiej oraz wysoko postawione cele są dużym wyzwaniem dla wszystkich gospodarek UE. Przez zastosowanie soft law Polska mogłaby wypracować własną koncepcję energetyczną opartą na węglu w powiązaniu z energetyką odnawialną. To pozwoliłoby na swobodne kształtowanie miksu energetycznego. Wśród działań dużym atutem byłoby również pozyskanie znacznie większych dotacji, co przyspieszyłoby nowe inwestycje, gdyż przy obecnej sytuacji jest to dużym wyzwaniem. Do poprawy sytuacji przyczyniłoby się również wynegocjowanie korzystniejszych limitów emisji $\mathrm{CO}_{2}$. Wypracowanie konsensusu z Unią Europejską pozwoliłoby utrzymać dominację węgla w sektorze energetycznym oraz w racjonalny sposób gospodarować zasobami złóż węgla. Czy istnieje możliwość osiągnięcia takich założeń? W znaczniej mierze losy węgla w perspektywie długoterminowej będą zależeć od polityki rządu. Prowadzone dywagacje bez przekształcenia w działanie nie pozwolą uniknąć procesu zmierzającego do dekarbonizacji. Polityka rządu powinna współdziałać na wszystkich płaszczyznach niezależnie od przynależności partyjnej. Dbanie o dobro narodowe, jakim jest węgiel, powinno być priorytetem dla rządu w celu zapewnienia bezpieczeństwa energetycznego.

\section{Zakończenie}

Globalny problem zmian klimatu sięga lat siedemdziesiątych XX wieku i ściśle wiąże się ze wspólnotową polityką energetyczną Unii Europejskiej. Wprowadzone długoterminowe działania mają za zadanie zahamować proces ocieplania klimatu. Proponowany i promowany przez Unię Europejską kierunek zwiększenia produkcji energii z OZE znajduje powszechne uznanie i akceptację. Głównym atutem odnawialnych źródeł energii jest niska emisja $\mathrm{CO}_{2}$, jak również niewyczerpalność niektórych źródeł. Celem Komisji Europejskiej w planie „Mapa drogowa do 2050 roku” jest całkowita rezygnacja z wykorzystania węgla do produkcji energii ze względu na znaczną emisję $\mathrm{CO}_{2}$. Prognozy dla węgla w polskim sektorze energetycznym do 2050 roku są optymistyczne. Polski sektor energetyczny, jako jeden z nielicznych w Unii, od wielu lat w znacznej mierze oparty jest na węglu, głównie z powodu zasobów tego surowca. Rząd powinien dążyć do wypracowania takich rozwiązań, które nie będą zakazywać wykorzystania tego cennego paliwa. Udział węgla w polskim sektorze energetycznym przez politykę Unii Europejskiej do 2050 roku będzie zdecydowanie mniejszy niż obecnie - z $80 \%$ spadnie do prognozowanych około 50-60\%. Ten procentowy udział zastąpi rozwijający się segment odnawialnych źródeł energii, który systematycznie będzie wzrastał i wspierał sektor energetyczny. Aktualnie sektor górnictwa przechodzi restrukturyzację. Nierentowne kopalnie są zamykane. Ich miejsce zajmą obecnie budowane nowoczesne wysoce wydajne ekologiczne bloki energetyczne zasilane węglem. Krajowe prace badawcze dają niepowtarzalną szansę na prawdziwy technologiczny skok, który pozwoli, by Polska stała się europejskim liderem w dziedzinie czystych technologii węglowych. Nowe tech- 
nologie zużywają mniej węgla, co niewątpliwie przyczyni się do mniejszej emisji zanieczyszczeń środowiska. Należy dołożyć wszelkich starań, aby rozwój czystych technologii węglowych nie został zahamowany. Pozwoli to na rozwój nowoczesnego polskiego przemysłu górniczego oraz zagwarantuje Polsce na długie dziesięciolecia niezależność i bezpieczeństwo energetyczne.

\section{Literatura}

Biała księga „Energia dla przyszłości - odnawialne źródła energii”, KOM(97)599, wersja ostateczna.

Biuletyn Urzędu Regulacji i Energetyki 2005, nr 6.

Doliwa-Klepacki Z.M., 2005, Integracja Europejska, Białystok.

Dyrektywa Parlamentu Europejskiego i Rady 2009/28/WE z dnia 23 kwietnia 2009 r.

Kaproń H., Połecki Z., 2012, Eksploatacja podsystemu wytwórczego w Polsce w latach 1995-2010, Rynek Energii, nr 6. s. 3-9.

Kasztelewicz Z., Zajączkowski M., Ptak M., 2015, Strategiczne determinanty rozwoju górnictwa $i$ energetyki wegla brunatnego w Polsce, Zeszyty Naukowe Instytutu Gospodarki Surowcami Mineralnymi i Energią Polskiej Akademii Nauk, nr 91.

Komisja Europejska, 2010, Komunikat Europa 2020. Strategia na rzecz inteligentnego i zrównoważonego rozwoju sprzyjajacego właczeniu społecznemu, Bruksela z dnia 3.3.2010 KOM (2010) 2020.

Komunikat Komisji do Rady Europejskiej i Parlamentu Europejskiego, Europejska Polityka Energetyczna, KOM (2007)1.

Pakiet dotyczący Unii Energetycznej, Bruksela, 25.2.2015 r., COM(2015)80.

Plan działania w zakresie energii do roku 2050, KOM(2011) 885.

Polityka energetyczna Polski do 2025 r., dokument przyjęty przez Radę Ministrów z dnia 4 stycznia 2005 roku.

Turek M., Jonek-Kowalska I., 2014, Kierunki rozwoju energetyki a rynek wegla kamiennego w Polsce, Zeszyt Naukowy Politechniki Śląskiej, nr kol. 1921.

Urbańska-Malucha M., 2013, Rynkowe mechanizmy w ochronie klimatu w Unii Europejskiej $i$ w Polsce, Prace Naukowe Uniwersytetu Ekonomicznego we Wrocławiu, nr 311.

Węgiel brunatny, 2015, Biuletyn Informacyjny nr 4(93).

Wojtkowska-Łodej G., 2015, Polityka klimatyczno-energetyczna Unii Europejskiej - wyzwania dla przyszłości polskiej gospodarki, t. 18, z. 1, s. 19.

Wojtkowska-Łodej G., Manteuffel W., 2009, Uwarunkowania, wyzwania i perspektywy dla polityki energetycznej Polski w kontekście polityki klimatycznej, Fundacja Centrum Stosunków Międzynarodowych, Warszawa.

Wyrwa A., Szurlej A., Gawlik L., Suwała W., 2015, Energy scenarios for Poland - a comparison of PRIMES and TIMES - PL modeling results, Journal of Power Technologies. 